Original Paper http://ajol.info/index.php/ijbcs http://indexmedicus.afro.who.int

\title{
Sero-prevalence of Human Immunodeficiency Virus and hepatitis viruses and their correlation with CD4 T-cell lymphocyte counts in pregnant women in the Buea Health District of Cameroon
}

\author{
Rebecca Enow-TANJONG ${ }^{1 *}$, Pride TEYIM ${ }^{1}$, Henry Lucien KAMGA ${ }^{2}$, Edwin Suh NEBA $^{1}$ \\ and Theresia NKUO-AKENJI ${ }^{3}$ \\ ${ }^{1}$ School of Health and Medical Sciences (SHMS), Kumbo. Catholic University of Cameroon (CATUC), \\ Bamenda. \\ ${ }^{2}$ Department of Medical Laboratory Sciences, Faculty of Health Sciences, University of Bamenda, Cameroon. \\ ${ }^{3}$ Department of Microbiology and Parasitology, Faculty of Science, University of Buea, Cameroon. \\ *Corresponding author; E-mail: becky_enow@yahoo.com
}

\section{ACKNOWLEDGMENTS}

This work was funded through Professor Peter Martins Ndumbe, by a grant from the European and Developing Countries Trial Partnership (EDCTP) through the Central African Network for Tuberculosis, AIDS and Malaria (CANTAM).

\begin{abstract}
Prior to this study, very few studies in Cameroon have addressed co-infection of HIV and hepatitis in pregnancy. The aim of this study was to screen pregnant women living in the Buea Health District for Human Immunodeficiency Virus (HIV), Hepatitis B Virus (HBV) and Hepatitis C virus (HCV) and determine how the prevalence of mono and co-infections relates to immunity. Eligible and consenting women were interviewed using a standardized questionnaire. After which $10 \mathrm{ml}$ of whole blood was collected from 406 pregnant women. All specimens were tested for HIV, HBV and HCV using Determine HIV1/2 (Abbott Co. Ltd., Japan), SD Bioline (Standard Diagnostics, INC., USA) and ELISA (Murex Biotech Limited, Temple Hill, UK; ABBOTT Laboratories, Wiesbaden, Germany). The prevalence of HIV, HBV and HCV mono-infection in this study was 34(8.37\%), 40(12.1\%) and 28(6.89\%) respectively. HIV/HBV, HIV/HCV, HBV/HCV and $\mathrm{HIV} / \mathrm{HBV} / \mathrm{HCV}$ multiple infection rates were $6(1.48 \%), 7(1.72 \%), 5(1.23 \%)$ and $2(0.49 \%)$ respectively and there was no statistical association between accessed risk factors and multiple viral infections in Pregnancy. Amongst women with a positive HIV result, those co-infected with $\mathrm{HBV}$ and $\mathrm{HCV}$ had the least mean $\mathrm{CD} 4^{+} \mathrm{T}$ cell lymphocyte counts $(531.50 \pm 6.18)$ while those infected only with HIV had the highest mean $\mathrm{CD} 4^{+} \mathrm{T}$-cell lymphocyte counts $(620.22 \pm 165.27)$. Co-infection of HIV, HBV and HCV reduced the immune competence$\mathrm{CD} 4^{+} \mathrm{T}$ cell counts, in pregnant women more than those who were HIV mono-infected.

(C) 2016 International Formulae Group. All rights reserved
\end{abstract}

Keywords: Mono-infection, multiple-infections, mother-to-child-transmission, CD4 T-cell lymphocyte, pregnancy.

\section{INTRODUCTION}

People living with HIV/AIDS (PLWH) were 34 million (Range 31.4-39.5 million) and AIDS deaths were 1.7million (Range 1.51.9 million) (Schwartlander et al., 2011). In 2013, WHO reported an increase in these 
figures stating that by the end of 2012, PLWH had increased to 35.3 million and 1.6 AIDS death occurred (WHO-HIV/AIDS Report, 2013). Due to the high estimated numbers of pregnant women living with HIV, Cameroon is one of 22 priority countries identified in the World Health Organization's “Global Plan” as a key target for HIV control and interventions (Gaynes et al., 2012).

Pregnancy is considered high risk when a woman is hepatitis B virus (HBV) infected and there is a $20 \%$ chance of transmission to the unborn infant. HBV is the most common form of Hepatitis worldwide and chronic carriers continue to transmit the virus years before symptoms appear. The mode of transmission in areas of high endemicity is mostly vertical (Tran, 2010; Hwang and Cheung, 2011; Komatsu et al., 2012). Of the hepatotrophic viruses (hepatitis A, B, C, D and $\mathrm{E}$ ), hepatitis $\mathrm{B}$ virus is most virulent and most versatile and is probably also the most prevalent of all viruses that affect humans (Park, 2011). In a study carried out in Ethiopia, it was found that the sero-prevalence of HBsAg in pregnant women was $3.7 \%$ (Awole and Gebre-Selassie, 2005; Esan et al., 2014; Molla et al., 2015).

In Cameroon, studies carried out revealed that the prevalence of hepatitis $B$ surface antigen in rural general populations was greater than $8 \%$ (Kfutwah et al, 2012). Presently, much of the work being done in Cameroon on HBV is focused on hepatitis among HIV patients and in one of such studies, the prevalence of HBV among adults starting ARV therapy was found to be $8.3 \%$ (Laurent et al., 2010).In the North West Region of Cameroon, it was determined that the prevalence of hepatitis B surface antigen in the general population was at $12.6 \%$ and male patients were more likely to have positive results than female patients (Zoufaly et al., 2011). More still has to be done in the South West Region of Cameroon as little data is available concerning the prevalence of
HBsAg and hepatitis B virus (HBV) infection may go undetected. Unawareness of an ongoing infection delays the diagnosis of HBV-related liver disease and favors the spread of the virus (Chan et al., 2012; Brouard et al., 2013; Molla et al., 2015).

In a study to demonstrate unawareness of HBV infection among patients in a clinic in Italy by Ippolito et al. (2011), it was noticed that up to $40.3 \%$ of the participants were not aware of their infection. The age group most likely to be affected around the world is the newborn population, particularly in areas with a high prevalence of disease and lack of identification of infected women whose infants are at risk for becoming chronic carriers and in regions with low spread perinatal screening and in- adequate use of newborn prophylaxis, horizontal transmission secondary to exposure to contaminated blood products, body fluids, or sexual contact become the primary modes of transmission of $\mathrm{HBV}$ in the young adult population (Komatsu et al., 2012).

Hepatitis $\mathrm{C}$ virus (HCV) which is also being reported is an RNA virus known to infect humans and chimpanzees, causing similar disease in these 2 species. $\mathrm{HCV}$ is most often transmitted parenterally but is also transmitted vertically and sexually (Karoney and Silika, 2013). Hepatitis C virus (HCV) is up to 4 times more infectious than HIV and it is the leading cause of chronic liver cancer (Karoney and Silika, 2013). Drops of the virus can get dry and remain infectious for 6 weeks at room temperature. It also requires less exposure than HIV to cause infection (Te and Jensen, 2010). The prevalence of HCV in the general population in Africa ranges between $0.1 \%$ and $17.5 \%$, depending on the country (Karoney and Silika, 2013). Little data is available on HCV morbidity and mortality in Africa. Of those HCV-infected patients who develop chronic liver disease $1.6 \%$ progress to Hepatocellular carcinoma (HCC), a condition 
with a mortality rate $>80 \%$ (Maheshwari and Thuluvath, 2010).

The prevalence of $\mathrm{HCV}$ infection in Cameroon is among the highest in the world, $7.9 \%$ as reported by Njouom et al. (2005) and comparable to that documented in the schistosomiasis-endemic areas of Egypt (Frank et al., 2000). Just like in Egypt, the high prevalence of $\mathrm{HCV}$ has been incriminated to interventions for tropical disease control during the colonial era (Jacques et al., 2010) and the use of unsterilized pricking equipment used for mass treatment on the general population with parenteral anti-schistosomal therapy from the 1920 s to the 1980 s or traditional practices (Mohamoud et al., 2013). Despite its high prevalence and highly infectious nature, $\mathrm{HCV}$ remains under-diagnosed and under reported in Africa (with the exception of Egypt). Low risk of transmission of $\mathrm{HCV}$ from mother to child has been reported in Cameroon (Pépin et al., 2010; Njouom et al., 2011).

All the three viruses have some common areas of interactions such as; shared routes of transmission- in blood either sexually or by injection drug use and motherto-child-transmission (M-T-C). HBV like HIV possess reverse transcriptase (Mims et al., 2006) and $5-25 \%$ of the 35.3 million people living with HIV worldwide are co-infected with either HBV or HCV or both (Okeke et al., 2012). The highest numbers of those coinfected are in low income countries (Okeke et al., 2012).

This study was carried out because previous studies on HIV and hepatitis coinfection in Cameroon have been on the general population and $90 \%$ of $\mathrm{HBV}$ transmissions are vertical with more women transmitting the Hepatitis B surface antigen (HBsAg). Also, it was to provide relevant data on current prevalence of HIV and hepatitis coinfection and their correlation to immunity $\left(\mathrm{CD}^{+} \mathrm{T}\right.$-cell counts) in pregnant women in the Buea Health District, South West Region of Cameroon.

\section{MATERIALS AND METHODS}

Ethical considerations

Ethical approval for this work was obtained from the Regional Delegation of Public Health, Buea, South-West Region and from the Ministry of Public Health, Yaounde, Cameroon. Participation was voluntary. A written consent was sought from all participants. All procedures were standard and only involved minimal risk to the participants.

\section{Study setting/Study population/ Eligibility criteria}

Study participants were recruited from Antenatal Clinics (ANCs) in the Buea Health District of Cameroon. A total of 407 participants were interviewed and criteria for recruitment were being pregnant and willing to participate in the study.

\section{Sample collection}

This was a demographic cohort study carried out in 2010. All eligible and consenting women were interviewed using a standardized questionnaire. After interview, the following samples were collected from each participant: $10 \mathrm{ml}$ of whole blood $(5 \mathrm{ml}$ was put in dry tubes to obtain serum while the remaining $5 \mathrm{ml}$ was put in EDTA tubes to obtain plasma). The blood samples collected were put in tube racks and transported in an ice-box containing ice to the Faculty of Health Science Laboratory, where all laboratory assays were done. Participants' results were returned and those of HIV-positive women after post-test counselling were directed into regular care by the nurses in the antenatal clinics. Two and a half milliliter $(2.5 \mathrm{ml})$ of whole blood was equally collected from children born of HIV positive mothers 18 months after delivery to test for HIV. 


\section{Sample analysis}

All specimens were tested for HIV, $\mathrm{HBV}$ and HCV using Determine HIV1/2 (Abbott Co. Ltd., Japan), SD Bioline (Standard Diagnostics, INC., USA) and ELISA (Murex Biotech Limited, Temple Hill, UK; ABBOTT Laboratories, Wiesbaden, Germany).The $\mathrm{CD} 4^{+} \mathrm{T}$-cell absolute count was determined using the Partec Cyflow Counter and the CD4 easy count kit (Partec GmbH, Germany).

\section{Statistical analysis}

Data was entered and checked for completeness using excel and analyzed using SPSS. Differences between groups were established for continuous data using the student t-test and the analysis of variance (ANOVA) while the Chi-square $\left(\mathrm{X}^{2}\right)$ analysis was used to establish difference between groups for categorical data. The correlation coefficient was calculated to establish a correlation between two variables. A P- value $<0.05$ was considered statistically significant.

\section{RESULTS}

\section{Description of participants' characteristics}

A total of 407 pregnant women were approached in the study but 406 consented and this gave a response rate of $95.54 \%$. Slightly less than one third $(30.5 \%)$ of the participants were primiparous. The age of participants ranged from 15 to 47 years with a mean of $26 \pm 5.56$ (Table 1$)$.

\section{Prevalence of HIV, HBV and HCV mono and multiple infections}

Twenty $(4.93 \%)$ of the 406 pregnant women tested positive for two or all three infections (HIV, HBV and HCV) screened in this study. Six [1.48\% $(\mathrm{P}=0.297)]$ were found to be co-infected with HIV and HBV, 07 [1.72\% $(\mathrm{P}=0.135)]$ with HIV and HCV, 05 [1.23\% $(\mathrm{P}=0.30)]$ with $\mathrm{HCV}$ and $\mathrm{HBV}$, and 2 $[0.49 \% \quad(\mathrm{P}=0.293)]$ were infected with all three infections as illustrated in Figure 1. These results were not statistically significant and none of the risk factors were associated with multiple infections as illustrated on Table 2.

\section{Mother-to-Child HIV transmission amongst HIV positive pregnant women \\ Of the 34 HIV infected pregnant women followed up in this study, $32(94.12 \%)$ gave birth to life children, and $3(8.82 \%)$ were lost to follow up, giving a successful follow up rate of 29 (85.29\%). Amongst the 29 children born of HIV positive mothers, 8 $(27.59 \%)$ were diagnosed to be HIV positive. \\ The mean $\mathrm{CD} 4^{+} \mathrm{T}$-cell count of the 29 mothers who gave birth to life children was $251.57 \pm 80.33$ (95\% CI: 221.01-282.13) while that of mothers who transmitted the virus to their children was $202.1 \pm 46.01(95 \%$ CI: 163.66-240.59).}

The impact of $\mathrm{HBV}$ and $\mathrm{HCV}$ co-infection on the immune competence of HIV positive pregnant women

Amongst women with a positive HIV result, those co-infected with $\mathrm{HBV}$ and $\mathrm{HCV}$ had the least mean $\mathrm{CD} 4^{+} \mathrm{T}$-cell lymphocyte counts $(531.50 \pm 6.18)$ while those infected only with HIV had the highest mean $\mathrm{CD} 4^{+} \mathrm{T}$ cell lymphocyte counts $(620.22 \pm 165.27)$ and there was a significant difference between the $\mathrm{CD}^{+}$T-cell lymphocyte counts of HIV positive only and HIV negative pregnant women $(\mathrm{P}=0.002)$. Amongst those who had a positive test result for at least one viral infection, those with a positive test result for both HBV and HCV had the highest mean $\mathrm{CD}^{+}$T-cell lymphocyte counts (843.00 \pm 223.54) and there was no significant difference between the $\mathrm{CD}^{+}$T-cell lymphocyte counts of $\mathrm{HCV}$ positive and negative pregnant women $(\mathrm{P}=0.602)$ as illustrated in Figure 2. 


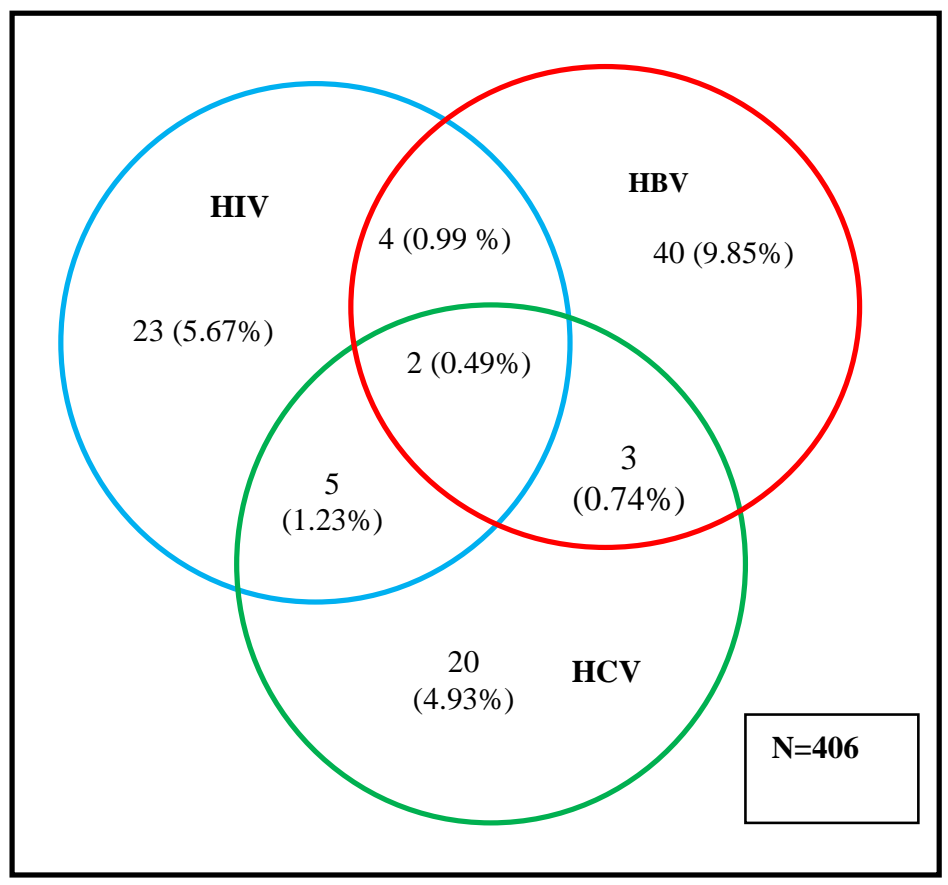

Figure 1: Distribution of HIV, HBV and HCV multiple infections amongst study population.

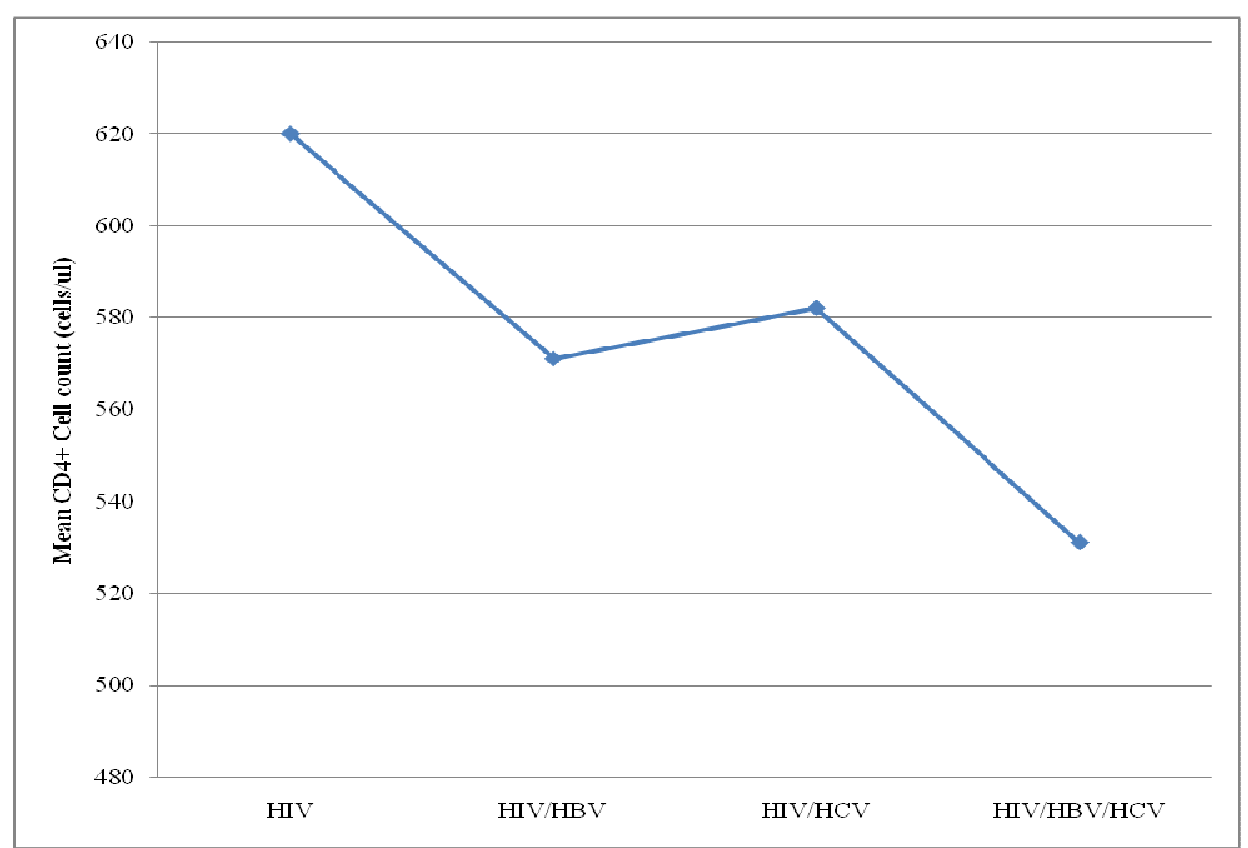

Figure 2: Distribution of Mean $\mathrm{CD} 4^{+} \mathrm{T}$-cell lymphocyte counts by Health Condition. 
Table 1: Distribution of Participants' Characteristics.

\begin{tabular}{lccc}
\hline Age group & Frequency & Percentages & Cumulative Percentages \\
\hline$\leq 25$ years & 187 & 46.1 & 46.1 \\
$\geq 26$ years & 219 & 53.9 & 100.0 \\
\hline Marital status & & & \\
Unmarried & 144 & 35.5 & 35.5 \\
Married & 256 & 63.1 & 98.5 \\
Widow/divorced & 6 & 1.5 & 100.0 \\
\hline Period of gestation & & & \\
$1^{\text {st }}$ trimester & 30 & 7.4 & 7.4 \\
$2^{\text {nd }}$ trimester & 160 & 39.4 & 46.8 \\
$3^{\text {rd }}$ trimester & 216 & 53.2 & 100.0 \\
\hline Number of gravidity & & & \\
1 & 141 & 34.7 & 64.9 \\
2 & 102 & 25.1 & 79.1 \\
3 & 79 & 19.5 & 91.8 \\
4 & 49 & 12.1 & 97.3 \\
5 & 22 & 5.4 & 99.0 \\
6 & 7 & 1.7 & 99.5 \\
7 & 2 & 0.5 & 100.0 \\
8 & 2 & 0.5 & 0.7 \\
\hline Education & & & 30.0 \\
No formal education & 3 & 0.7 & 73.9 \\
Primary & 119 & 29.3 & 100.0 \\
Secondary & 178 & 43.8 & 43.3 \\
Tertiary & 106 & 26.1 & 64.5 \\
\hline Occupation & 176 & 43.3 & 84.2 \\
Semi-skilled & 86 & 21.2 & \\
Skilled & 80 & 19.7 & \\
Student/apprentice & & & \\
\hline
\end{tabular}


Table 2: Risk factors to multiple viral infections in pregnancy.

\begin{tabular}{|c|c|c|c|c|c|c|c|c|c|c|c|c|}
\hline \multirow{2}{*}{\begin{tabular}{|l} 
Risk factors \\
Age Group
\end{tabular}} & \multicolumn{2}{|c|}{ HIV/HBV } & p-Valve & \multicolumn{2}{|c|}{ HIV/HCV } & \multirow[t]{2}{*}{ p-Valve } & \multicolumn{2}{|c|}{ HBV/HCV } & \multirow[t]{2}{*}{ p-Valve } & \multicolumn{2}{|c|}{ HIV/HBV/HCV } & \multirow{3}{*}{$\begin{array}{l}\text { p-Valve } \\
0.911\end{array}$} \\
\hline & Neg & Pos & \multirow{3}{*}{0.529} & Neg & Pos & & Neg & Pos & & Neg & Pos & \\
\hline$\leq 25$ & 185 & 2 & & 185 & 2 & \multirow[t]{2}{*}{0.349} & 185 & 2 & \multirow[t]{2}{*}{0.784} & 186 & 1 & \\
\hline$\geq 26$ & 215 & 4 & & 214 & 5 & & 216 & 3 & & 218 & 1 & \\
\hline \multicolumn{13}{|l|}{ Marital status } \\
\hline Unmarried & 140 & 4 & \multirow{3}{*}{0.271} & 141 & 3 & \multirow{3}{*}{0.254} & 142 & 2 & \multirow{3}{*}{0.946} & 142 & 2 & \multirow{3}{*}{0.161} \\
\hline Married & 254 & 2 & & 252 & 4 & & 253 & 3 & & 256 & 0 & \\
\hline Widow/Divorce & 6 & 0 & & 6 & 0 & & 6 & 0 & & 6 & 0 & \\
\hline \multicolumn{13}{|l|}{ Educational level } \\
\hline No formal education & 3 & 0 & \multirow{4}{*}{0.727} & 3 & 0 & \multirow{4}{*}{0.369} & 3 & 0 & \multirow{4}{*}{0.533} & 3 & 0 & \multirow{4}{*}{0.462} \\
\hline Primary & 118 & 1 & & 117 & 2 & & 119 & 0 & & 119 & 0 & \\
\hline Secondary & 174 & 4 & & 173 & 5 & & 175 & 3 & & 176 & 2 & \\
\hline Tertiary & 105 & 1 & & 106 & 0 & & 104 & 2 & & 106 & 0 & \\
\hline \multicolumn{13}{|l|}{ Occupation } \\
\hline Unskilled & 173 & 3 & & 172 & 4 & & 175 & 1 & & 175 & 1 & \\
\hline Skilled & 85 & 1 & \multirow{3}{*}{0.473} & 85 & 1 & \multirow{3}{*}{0.454} & 84 & 2 & \multirow{3}{*}{0.673} & 86 & 0 & \multirow{3}{*}{0.506} \\
\hline Student/apprentice & 80 & 0 & & 80 & 0 & & 79 & 1 & & 80 & 0 & \\
\hline House wife/Unemployed & 62 & 2 & & 62 & 2 & & 63 & 1 & & 63 & 1 & \\
\hline
\end{tabular}




\section{DISCUSSION}

Cameroon is part of Sub-Saharan Africa, a region where $68 \%$ of all people living with HIV reside (UNAIDS, 2013). It is estimated that 550,000 of the world's 35.3 million people are currently living with HIV in Cameroon (WHO-HIV/AIDS, 2013) with an HIV prevalence of $5.5 \%$ (Gaynes et al., 2012). The South West Region of Cameroon represents one of the high HIV burden regions with an estimated $8 \%$ prevalence (Ndjeng, 2013). This study reveals an HIV prevalence of $8.4 \%$ in pregnant women attending antenatal clinics the Buea.

The prevalence of HBsAg among pregnant women was found to be $12.1 \%$. This is relatively high in view of the fact that a vast majority of participants were asymptomatic. In comparison with studies from other parts of the same country, the prevalence reported in this study was higher than the $1.2 \%, 7.85 \%$, $7.7 \%$ and $9.7 \%$ reported by Thumamo and Asoquo (2004), Kfutwah et al. (2012), Fomulu et al. (2013) and Frambo et al. (2014) respectively. This difference may be because of different socioeconomic status and the natural difference attached to different geographic zones. Our prevalence was also higher than the $5.4 \%$ reported in the early nineties by Ndumbe et al. (1994) in rural pregnant women in Cameroon. We however had similar results with Florent et al. (2012), who found a prevalence of $12.14 \%$ amongst blood donors at the Blood Bank of the Central Hospital, Yaoundé (Cameroon). Similar results were also recorded by Zoufaly et al. (2012) who found a prevalence of $12.6 \%$ among HIV patients initiating antiretroviral therapy in the North-West Region of Cameroon. We however expected this high prevalence and this is in conformity with the established fact that HBsAg is endemic in African countries south of the Sahara desert of which Cameroon is among (Ndumbe et al., 1994). This level of carrier state in women of reproductive age will suggest that there is a high risk of mother-to-infant transmission in the Buea Health District. However, HBsAg carrier state alone in a pregnant woman does not put the fetus at a huge risk of being infected, instead, pregnant women who are positive both for HBsAg and HBeAg are more likely to infect their babies. Transmission does not only depend on $\mathrm{HBsAg}$ and $\mathrm{HBeAg}$ status but also on anti-HBeAg status. Anti-HBeAg positivity tends to prevent transmission (Okada et al., 1976; Umar et al., 2013).

Africa has the highest WHO estimated regional $\mathrm{HCV}$ prevalence $(5.3 \%)$. The prevalence of $\mathrm{HCV}$ in the general population in Africa ranges between $0.1 \%$ and $17.5 \%$, depending on the country (Karoney and Silika, 2013). The prevalence of HCV in this study is $6.9 \%$. Many studies have shown that the prevalence of $\mathrm{HCV}$ increase with Age. Participants in our study had ages that ranged from 15 to 47 years with a mean age of $26 \pm$ 5.56. Though there was no statistically significant difference between those aged less than or equal to 25 years and those greater than 25 years in this study, we however noticed that those with ages greater than 25 years were more infected than those less than 25 years.

The overall hepatitis (B and C) and HIV co-infection rate in this study was $4.9 \%$. This implies that one in every twenty pregnant women is at risk of transmitting both HIV and $\mathrm{HBV}$ or $\mathrm{HCV}$, a deadly combination for which a real cure does not yet exist, not only to their spouse but to their future offspring. Appropriate measures need to be taken to reduce the spread of these infections. Although it is postulated that trans-placenta $\mathrm{HCV}$ transmission is very rare, the risk of mother to child $\mathrm{HCV}$ transmission remains very high as the child may become infected either at delivery or by the intimate contact between mother and child (Murad et al., 2013).

Lower prevalence rates for the coinfection of HIV-HBV and HIV-HCV were recorded by Florent et al. (2012) amongst blood donors in the Yaoundé Central Hospital blood bank. Higher prevalence of HIV-HBV and HIV-HCV were however obtained by Laurent et al. (2010) and Florent et al. (2012) in Yaounde. Indeed, Laurent et al. (2010) 
found among HIV-positive patients, $8.3 \%$ and $12.4 \%$ co-infections with $\mathrm{HBV}$ and $\mathrm{HCV}$, respectively. But these results were obtained from 169 HIV-positive people eligible for antiretroviral therapy, thus at a more advanced stage of the HIV infection.

In this study, the prevalence of Mother to child transmission of HIV is $27.6 \%$. In well-resourced health care systems, such as those in the United States, there has been dramatic progress in reducing mother to child transmission of HIV infection. Early identification of HIV infection in pregnant women through routine antenatal HIV testing; immediate assessment of HIV-infected pregnant women for their need for treatment for their own health; and provision of antiretroviral treatment when needed or antiretroviral prophylaxis if therapy is not yet required has substantially reduced the risk of infection among infants during pregnancy and delivery. When combined with elective caesarean delivery and complete avoidance of breastfeeding, these interventions have reduced the risk of HIV transmission to $1 \%-$ 2\% (Townsend et al., 2008).

Our study shows that all eight $(100 \%)$ HIV infected children born of HIV infected mothers where born through the vaginal route. $87.5 \%$ of these pregnancies where not planned and their mothers were not on any ART. This proves the non-application of WHO recommendations on measures to prevent mother to child HIV transmission in most resource limited countries. Since 2004, WHO guidelines recommended the use of more efficacious multidrug antiretroviral regimens for the treatment and prevention of mother to child HIV transmission. These measures also included the use of highly active antiretroviral therapy for women with advanced disease and short course dual prophylaxis for healthier women not yet eligible for treatment (WHO, 2009).

The application of WHO recommendations remains a major challenged in resource limited countries such as Cameroon for many reasons such as maintaining adequate supplies of HIV tests kits and medications, a shortage of maternal and child health staff, the reliance on medical doctors for antiretroviral treatment initiation and the weak linkages between HIV diagnosis in pregnancy and antiretroviral therapy services, which often preclude women from being fast-tracked into HIV care and treatment programs. As a result of this limited capacity, many countries are unable to adapt their existing health systems according to World Health Organization preventing mother to child HIV transmission guidelines, which are amended as new evidence becomes available and more cost-effective in the long-term. Therefore, many health services are not providing HIV-infected women with the most effective drugs. One example of this is the use of single-dose nevirapine, an antiretroviral drug which, despite no longer being recommended by the WHO, in 2011 is still being used in many countries for preventing mother to child HIV transmission including Cameroon.

Findings from our study also revealed that the mean $\mathrm{CD} 4^{+} \mathrm{T}$ cell count of the mother who failed to transmit HIV to their children was $503.14 \pm 160.665 \quad(95 \% \quad \mathrm{CI}$ : 442.02,564.25) while that of mothers who transmitted the virus to their children was $392.38 \pm 186.61$ (95\% CI: 236.36, 548.39). Our study revealed that women who were tested positive for HIV, HBV and HCV triple infection had lower $\mathrm{CD}^{+}$cell counts than those who were either co-infected with $\mathrm{HIV} / \mathrm{HCV}$ or HIV/HBV and even those who tested positive for only HIV infection. These findings were similar to those of Olufemi et al. (2009) in Nigeria who demonstrated that the mean $\mathrm{CD} 4+\mathrm{T}$ cell counts of those who test positive $\mathrm{HIV} / \mathrm{HCV}$ and HIV/HBV coinfections were lower than those who tested positive for HIV mono infection. However, studies carried out by Yitayih et al. (2013) showed that there was no statistically significant CD4 count mean difference between HIV mono-infected, HIV/HBV and HIV/HCV co-infected study participants. These controversial results may be partly due to the differences in the immune status of the 
study participants or it may be due to the viral hepatitis. A study by Hooja et al. (2015) also proved that HIV infection may accelerate the progression of hepatic complications.

We also wish to acknowledge that our study failed to consider some factors such as duration of antiretroviral therapy for those already on antiretroviral therapy, assess if the participants who were infected with $\mathrm{HCV}$ and HBV were acute or chronic carriers. All of these factors may have an indirect effect on the $\mathrm{CD} 4^{+} \mathrm{T}$-cell counts of our study participants.

\section{Conclusion}

The prevalence of HIV, HBV and HCV mono infections in pregnant women living in the Buea, South West Region of Cameroon remains relatively higher than most other areas in which similar studies were carried out in Cameroon. The co-infection of HIV, HBV and $\mathrm{HCV}$ in pregnant women in this study was however lower than in the general population and multiple infection of HIV, $\mathrm{HBV}$ and $\mathrm{HCV}$ reduced the immune competence $\left(\mathrm{CD} 4^{+} \mathrm{T}\right.$-cell counts) in pregnant women more than those who were HIV monoinfected.

Over a quarter of Children born of HIV positive pregnant women were tested positive for HIV. The non-application of WHO (2009) measures to prevent mother to child HIV transmission such as the use of antiretroviral treatment when needed or antiretroviral prophylaxis if therapy is not yet required, programmed pregnancies, elective caesarean delivery and complete avoidance of breastfeeding have been incriminated as main factors associated with mother to child HIV transmission in this study.

\section{COMPETING INTERESTS}

The authors declare that they have no competing interests.

\section{AUTHORS' CONTRIBUTIONS}

RE-T was the principal investigator and data collector. ESN assisted in the data collection. PT did the data analysis. HLK and
TN-A designed and supervised the work. All the authors read and approved the final copy of the manuscript.

\section{REFERENCES}

Adewole OO, Anteyi E, Ajuwon Z, Wada IW, Elegba F, Ahmed P, Betiku Y, Okpe A, Eze S, Ogbeche T, Erhabor GE. 2009. Hepatitis B and C virus coinfection in Nigerian patients with HIV infection. Journal of Infectious Dev Ctries, 3(5): 369-375. DOI: http://www.jidc.org/index.php/journal/a rticle/view/19759507

Awole M, Gebre-Selassie S. 2005. Seroprevalence of $\mathrm{HBsAg}$ and its risk factors among pregnant women in Jimma, Southwest- Ethiopia. Ethiopian Journal of Health Development, 19(1): 45-51. DOI: 10.12691/ajbr-2-1-3.

Brouard C, Gautie A, Saboni L, Jestin C, Semaille C, Beltzer N. 2013. Hepatitis $\mathrm{B}$ knowledge, perceptions and practices in the French general population: the room for improvement. BMC Public Health, 13: 576. DOI: 10.1186/14712458-13-576.

Chan OK, Lao TT, Suen SH, Leung TY. 2012. Deficient knowledge on Hepatitis $\mathrm{B}$ infection in pregnant women and prevalence of Hepatitis B surface antigen carriage in an endemic area: A review. Hepatitis Research and Treatment, 2012, Article ID 317451, 8pages. DOI: http://dx.doi.org/10.1155/2012/317451.

Esan AJ, Omisakin CT, Ojo-Bola T, Owoseni MF, Fasakin KA, Ogunleye AA. 2014. Sero-Prevalence of Hepatitis B and Hepatitis C Virus Infection among Pregnant Women in Nigeria. American Journal of Biomedical Research, 2(1):11-15. DOI: 10.12691/ajbr-2-1-3.

Florent FY, Basile K, Jeanne H, Nadege K, Sandrine M, Jacqueline D. 2012. High Rates of Hepatitis B and C and HIV Infections among Blood Donors in Cameroon: A Proposed Blood Screening Algorithm for Blood Donors 
in Resource-Limited Settings Journal of Blood Transfusion, 2012, Article ID 458372, 7 pages. DOI: http://dx.doi.org/10.1155/2012/458372.

Fomulu NJ, Morfaw FL, Torimiro JN, Nana P, Koh MV, William T. 2013. Prevalence, correlates and pattern of Hepatitis B among antenatal clinic attenders in Yaounde-Cameroon: is perinatal transmission of $\mathrm{HBV}$ neglected in Cameroon? BMC Pregnancy Childbirth, 13: 158. DOI: 10.1186/1471-2393-13-158.

Frambo AA. B, Atashili J, Fon PN, Ndumbe PM. 2014. Prevalence of HBsAg in Pregnancy in the Buea Health District, Cameroon: a cross-sectional study. BMC Research Notes, 7: 394. DOI: 10.1186/1756-0500-7-394.

Gaynes BN, Pence BW, Atashili J, O’Donnell J, Kats D, Ndumbe PM. 2012. Prevalence and predictors of major depression in HIV-infected patients on antiretroviral therapy in Bamenda, a semi-urban center in Cameroon. PLoS ONE, 7(7): e41699. DOI: 10.1371/journal.pone.0041699.

Hooja S, Singhal A, Bachhiwal R, Yadav R, Vyas N. 2015. Hepatitis B virus seroprevalence and its correlation with CD4 cells and liver enzymes among human immunodeficiency virus positive individuals at a tertiary care hospital in North-West India. Int J Appl Basic Med Res., 5(1): 36-40. DOI: 10.4103/2229-516X.149235

Hwang EW, Cheung R. 2011. Global epidemiology of hepatitis B virus (HBV) infection. NAJ Med Sci., 4(1): 7-13. DOI: $10.5455 / 2320$ 6012.ijrms20150117.

Ippolito AM, Niro GA, Fontana R, Lotti G, Gioffreda D, Valvano MR, Iacobellis A, Di Mauro L, Stroffolini T, Andriulli A. 2011. Unawareness of $\mathrm{HBV}$ infection among in-patients in a Southern Italian hospital. Journal of Viral Hepatitis, 18(7): e206-211. DOI: 10.1111/j.1365-2893.2010.01432.x.
Jacques P, Myriam L, Oliver GP, Régis P, Yacouba F, Dominique R, AnnieClaude L, Richard N. 2010. Risk Factors for Hepatitis C Virus Transmission in Colonial Cameroon. Clin. Infect. Dis., 51(7): 768-776. DOI: 10.1086/656233.

Karoney MJ, Siika AM. 2013. Hepatitis C virus (HCV) infection in Africa: a review. Pan Afri. Med J., 2013(14): 14. DOI: 10.11604/pamj.2013.14.44.2199.

Kfutwah AK, Tejiokem MC, Njouom R. 2012. A low proportion of $\mathrm{HBeAg}$ among HBsAg-positive pregnant women with known HIV status could suggest low perinatal transmission of HBV in Cameroon. Virol J., 2012(9): 62. DOI: 10.1186/1743-422X-9-62.

Komatsu H, Inui A, Sogo T, Tateno A, Shimokawa R, Fujisawa T. 2012. Tears from children with chronic hepatitis $\mathrm{B}$ virus (HBV) infection are infectious of $\mathrm{HBV}$ transmission: experimental transmission of tears, using mice with chemeric human liver. J. Infect Dis., 206(4): 478-85. DOI: 10.1093/infdis/jis293.

Laurent C, Bourgeois A, Mpoudi-Ngolé E, Kouanfack C, Ciaffi L, Nkoué N, Mougnutou R, Calmy A, Koulla-Shiro S, Ducos J, Delaporte E. 2010. High rates of active hepatitis $\mathrm{B}$ and $\mathrm{C}$ coinfections in HIV-1 infected Cameroonian adults initiating antiretroviral therapy. HIV Medicine, 11(1): $85-89$. DOI: $10.1111 / j .1468-$ 1293.2009.00742.x.

Maheshwari A., Thuluvath PJ. 2010. Management of acute hepatitis C. Clin Liver Dis., 14(1): 169-176. DOI: 10.1016/j.cld.2009.11.007.

Mims C, Dockrell H, Goering R, Roitt I, Wakelin D. Zuckerman M. 2006. Medical Microbiology (Updated $3^{\text {rd }}$ edn). Elsevier Mosby: London.

Mohamoud YA, Mumtaz GR, Riome S, Miller D, Abu-Raddad L. 2013. The epidemiology of hepatitis $\mathrm{C}$ virus in Egypt: a systemic review and data 
synthesis. BMC Infectious Diseases, 2013(13): 288. DOI: $10.1186 / 1471-$ 2334-13-288.

Molla S, Munshea A, Nibret E. 2015. Seroprevalence of hepatitis B surface antigen and anti HCV antibody and its associated risk factors among pregnant women attending maternity ward of Felege Hiwot Referral Hospital, northwest Ethiopia: a cross sectional study. Virol J., 2015(12): 204. DOI: 10.11/S12985-015-0437-7

Murad EA, Babiker SM, Gasim I S, Rayis DA, Adam I. 2013. Epidemiology of hepatitis $\mathrm{B}$ and hepatitis $\mathrm{C}$ virus infections in pregnant women in Sana'a, Yemen. BMC Pregnancy and Childbirth, 13: 127. DOI: 10.1186/1471-2393-13-127.

Ndjeng O, Manuella Y, Prudence M. 2013. HIV AIDS in Cameroon - an update Available: http://www. Foretia foundation.org/hiv-aids-in-cameroonan-update/

Ndumbe PM, Skalsky J, Joller-Jemelka H. 1994. Seroprevalence of hepatitis and HIV infection among rural pregnant women in Cameroon. Apmis, 102: 662666. DOI/10.1111/

Njouom R, Lavoie M, Foupouapouoognigni Y, Frost E, Deslandes S, MamadouYaya F, Mbélesso P, Mbagingai S, Pépin J. 2011. Transmission of Hepatitis C virus among spouses in Cameroon and Central African Republic. J. Med. Virol., 3(12): 21132118. DOI: $10.1002 / \mathrm{mv} .22225$.

Okada K, Kamiyama I, Inomata M, Imai M, Miyakawa Y, Mayumi M. 1976. E antigen and anti-E in the serum of asymptomatic carrier mothers as indicators of positive and negative transmission of hepatitis B virus to their infants. N Engl J. Med., 294: 746749.

Okeke TC, Obi SN, Okezie OA, Ugwu EO, Akogu SP, Ocheni S, Ezenyeaku CC. 2012. Coinfection with hepatitis B and $\mathrm{C}$ viruses among HIV positive pregnant women in Enugu south east, Nigeria. Niger J Med. 21(1): 57-60. http://www.ncbi.nlm.nih.gov/pubmed/2 3301449

Park K. 2011. Epidemiology of communicable diseases; viral hepatitis, hepatitis B. In Park's Textbook of Preventive and Social Medicine $\left(21^{\text {st }}\right.$ edn). Amazon.com, Inc. 192-197.

Pépin J, Lavoie M, ybus OG, Pouillot R, Foupouapouognigni Y, Rousset D, Labbé AC, Njouom R. 2010. Risk factors for hepatitis $\mathrm{C}$ virus transmission in colonial Cameroon. Clin. Infect. Dis., 51(7): 768-76. DOI: 10.1086/656233.

Schwartlander B, Stover J, Hallet T, Atun R, Avila C, Gouws E, Bartos M, Ghys PD, Opun M, Barr D, Alsallaq R, Bollinger L, Freitas M, Garnett G, Holmes C, Legins K, Pillay $\mathrm{Y}$, Stanciole AE, McClure G, Hirnschall G, Laga MM, Padian N. 2011. Towards an improved investment approach for an effective response to HIV/AIDS. The Lancet, 377(9782): 2031-2041. DOI: 10.1016/S0140-6736(11)60702-2.

Te HS, Jensen DM. 2010. Epidemiology of hepatitis B and C viruses: a global overview. Clin Liver Dis., 14(1): 1-21. DOI: 10.1016/j.cld.2009.11.009.

Thumamo PB, Asoquo AE. 2005. Hepatitis B Surface Antigen (HBsAg) in Female Students and Pregnant Women in the West Province of Cameroon. Mary Slessor J. Med., 4: 53-57. DOI: 10.1186/1756-0500-7-394.

Townsend CL, Cortina-Boria M, Peckham CS. 2008. Low rates of mother-to-child transmission of HIV following effective pregnancy interventions in the United Kingdom and Ireland, 20002006. AIDS, 22: 973-981. DOI: 10.1097/QAD.0b013e3282f9b67a.

Tran TT. 2010. Management of hepatitis B in pregnancy: weighing the options. Cleveland Clinic Journal of Medicine, 76(3): 25-29. 
UNAIDS. 2013. Cameroon. Sourced at: www.unaids.org/en/regioncountries/co untries/cameroon on the 2013-11-25.

Umar M, Bushra H, Umar S, Khan HA. 2013. HBV Perinatal Transmission. Journal of Hepatology, 2013(2013), Article ID 875791, 7. http://dx.doi.org/10.1155/ 2013/875791

World Health Report 2004. http://www.who. $\mathrm{int} / \mathrm{whr} / 2004 / \mathrm{en} / \mathrm{on}$ the 2013-1-20.

WHO World Health Statistics, 2009. Sourced at https://www.google.com/search? $\mathrm{q}=\mathrm{WHO}+$ Report $+2009 \& \mathrm{ie}=\mathrm{utf}-8 \& \mathrm{ee}=$ utf-8 on 2013-1-20

WHO/World Hepatitis Alliance. 2011. World Hepatitis Day Factsheet. Sourced at www.worldhepatitisalliance.org accessed on the 2011-10-21.

WHO-HIV/AIDS. 2013. Sourred at: www.who.int/hiv/en/ on 25-11-2013 at $9: 25$
Yitayih W. Meseret A. Fanaye A, Yeshambel B. 2013. HBV and HCV seroprevalence and their correlation with CD4 cells and liver enzymes among HIV positive individuals at University of Gondar Teaching Hospital, Northwest Ethiopia. Virol. J. 10: 171 . DOI: $10.1186 / 1743-422 \mathrm{X}-10$ 171

Zoufaly A, Onyoh EF, Tih PM, Awasom CN, Feldt T. 2012. High prevalence of hepatitis B and syphilis co-infections among HIV patients initiating antiretroviral therapy in the North-West region of Cameroon. Int J STD AIDS, 23(6): 435-438. DOI: $10.1258 /$ ijsa. 2011.011279 . 